\title{
New Data on Distribution and Population Number of Large Birds of Prey in Nizhny Novgorod Region, Russia
}

\section{НОВЫЕ ДАННЫЕ О РАСПРОСТРАНЕНИИ И ЧИСЛЕННОСТИ КРУПНЫХ ХИЩНЫХ ПТИЦ В НИЖЕГОРОДСКОЙ ОБЛАСТИ, РОССИЯ}

\author{
Shukov P.M. (Minin Nizhny Novgorod State Pedagogical University, Nizhny Novgorod \\ branch of the Russian Bird Conservation Union, Nizhny Novgorod, Russia) \\ Шуков П.М. (ФГБОУ ВО «Нижегородский государственный педагогический \\ университет им. Козьмы Минина», Нижегородское отделение Союза охраны птиц \\ России, Нижний Новгород, Россия)
}

\author{
Контакт: \\ Павел Шуков \\ Нижегородский \\ государственный \\ педагогический \\ университет им. \\ Козьмы Минина \\ 603002, Россия \\ Нижний Новгород, \\ ул. УАьянова, 1 \\ shukov.pm@gmail.com
}

\section{Contact:}

Pavel Shukov

Minin Nizhny Novgorod

State Pedagogical

University, Nizhny

Novgorod branch of the

Russian Bird Conserva-

tion Union, Nizhny

Novgorod, Russia

Ulianova str, 1

Nizhniy Novgorod

Russia, 603002

shukov.pm@gmail.com

\section{Резюме}

В статье приведены новые данные о распространении и результаты анаииза современной численности 8 видов крупных хишных птиц (беркут Aquila chrysaetos, орёл-могильник A. heliaca, большой подорлик $A$. clanga, мамый подорлик A. pomarina, орёл-карлик Hieraaetus pennatus, орлан-белохвост Haliaeetus albicilla, змееял Circaetus gallicus и скопа Pandion haliaetus) в Нижегородской области. В 2014-2018 гг. был выявлен 151 гнезАовой участок этих видов. Современная численность беркута 7-16 пар, большого подорлика - 90-100 пар, мамого подорлика - неизвестна, орла-карлика - 104-111 пар, орлана-белохвоста - 70-80 пар, скопы - 50-60 пар, змееяла - 80-90 пар. Орёл-могильник исчез на гнездовании.

Киючевые слова: пернатые хишники, хишные птицы, орлы, Нижегородская область, змееял, беркут, орёлмогильник, большой подорлик, мамый подорлик, орёл-карлик, орлан-белохвост, скопа.

Поступияа в реАакцию: 22.11.2018 г. Принята к публикации: 15.01.2019 г.

\section{Abstract}

The article presents new data on the distribution of 8 species of large birds of prey (Golden Eagle Aquila chrysaetos, Imperial Eagle A. heliaca, Greater Spotted Eagle A. clanga, Lesser Spotted Eagle A. pomarina, Booted Eagle Hieraaetus pennatus, White-Tailed Eagle Haliaeetus albicilla, Short-Toed Eagle Circaetus gallicus and Osprey Pandion haliaetus) and analysis of the current numbers of these species in the Nizhny Novgorod Region. In 2014-2018, 151 breeding territories of these species were identified. The current number of the Golden Eagle is 7-16 pairs, the Greater Spotted Eagle is 90-100 pairs, the Lesser Spotted Eagle is unknown, the Imperial Eagle is extinct in the region, the Booted Eagle is 104-111 pairs, the White-Tailed Eagle is 70-80 pairs, the Osprey is 50-60 pairs, the Short-Toed Eagle - is 80-90 pairs. Keywords: raptors, birds of prey, eagles, Nizhniy Novgorod, Short-Toed Eagle, Golden Eagle, Imperial Eagle, Greater Spotted Eagle, Lesser Spotted Eagle, Booted Eagle, White-Tailed Eagle, Osprey.

Received: 22/11/2018. Accepted: 15/01/2019.

DOI: $10.19074 / 1814-8654-2019-38-127-136$

\section{Введение}

На территории Нижегородской области обитает 8 видов крупных хишных птиц беркут (Aquila chrysaetos), орёл-могильник (A. heliaca), большой подорлик (A. clanga), малый подорлик (A. pomarina), орёл-кармик (Hieraaetus pennatus), орлан-белохвост (Haliaeetus albicilla), змееял (Circaetus gallicus) и скопа (Pandion haliaetus). За последние 5 лет мия всех из них были получены новые данные по распространению, а также проведена оценка современной численности с применением ГИС-методов, учитывая данные из последнего издания Красной книги Нижегородской области (Красная книга, 2014).

\section{Методика}

В основе Аанной публикации лежат результаты мониторинга реАких видов хишных птиц, проводившегося в Нижегородской области в период 2014-2018 гг. За это время были обследованы практически

\section{Introduction}

On the territory of the Nizhny Novgorod region there are 8 species of large birds of prey - the Golden Eagle (Aquila chrysaetos), the Imperial Eagle ( $A$. heliaca), the Greater Spotted Eagle (A. clanga), the Lesser Spotted Eagle ( $A$. pomarina), the Booted Eagle (Hieraaetus pennatus), the White-Tailed Eagle (Haliaeetus albicilla), the Short-Toed Eagle (Circaetus gallicus) and the Osprey (Pandion haliaetus). Over the past 5 years, for all species new distribution data were obtained, and the current population was estimated by means of GIS methods, the latest edition of the Red Data Book of the Nizhny Novgorod Region was taking into account (Red Data Book, 2014). In total, 151 breeding areas of large birds of prey were identified (table 1).

\section{Results}

Golden Eagle (Aquila chrysaetos)

In 2007, the population of the Golden 
Табл. 1. Количество выявленных гнездовых участков крупных хишных птиц в Нижегородской области в 2014-2018 гг.

Table 1. The number of identified breeding areas of large birds of prey in the Nizhny Novgorod region in 2014-2018.

\begin{tabular}{|c|c|c|c|}
\hline Вим Species & $\begin{array}{r}\text { Подтвержаённые } \\
\text { участки } \\
\text { Confirmed territories }\end{array}$ & $\begin{array}{r}\text { Новые участки } \\
\text { Newly found } \\
\text { territories }\end{array}$ & $\begin{array}{r}\text { Bcero участков } \\
\text { Total }\end{array}$ \\
\hline Беркут / Golden Eagle (Aquila chrysaetos) & 7 & 0 & 7 \\
\hline Большой подорлик / Greater Spotted Eagle (Aquila clanga) & 3 & 29 & 32 \\
\hline Малый подорлик / Lesser Spotted Eagle (Aquila pomarina) & 0 & 3 & 3 \\
\hline Орёл-могильник / Imperial Eagle (Aquila heliaca) & 0 & 0 & 0 \\
\hline Орёл-карлик / The Booted Eagle (Hieraaetus pennatus) & 4 & 15 & 19 \\
\hline Орлан-белохвост / White-Tailed Eagle (Haliaeetus albicilla) & 8 & 24 & 32 \\
\hline Скопа / Osprey (Pandion haliaetus) & 8 & 11 & 19 \\
\hline Змееял / Short-Toed Eagle (Circaetus gallicus) & 4 & 35 & 39 \\
\hline Bcero / Total & 34 & 117 & 151 \\
\hline
\end{tabular}

все самые важные природные территории региона, на которых можно бымо бы предполагать намичие неизвестных участков крупных хишных птиц. Нужно отметить, что большее внимание улелялось именно поиску новых гнездовых территорий, проверка ранее известных местообитаний осушествлялась не Аля всех районов.

Проводился предварительный анализ наиболее вероятных местообитаний реАких виАов хишных птиц по космическим снимкам с использованием ГИС-систем QGis и ArcView. Использовались также материамы базы данных Нижегородского отделения СОПР по гнезАовым участкам, находкам гнёзд и встречам этих видов.

Аля проведения исследований ежегодно планироваяась система маршрутов. Обшая протяжённость автомобильных маршрутов составила более 25000 км, пеших - более 4000 км. Наибольшее внимание при этом уделялось крупным болотным комплексам, поймам рек, гарям, сохранившимся степным участкам. На маршрутах решались комплексные замачи по поиску всех видов редких хишных птиц, также несколько экспедиций было проведено мия изучения конкретных видов - обследование местообитаний большого подорлика в черноольховых болотах пойм рек Волга и Ока и поиск новых участков орлана-белохвоста вАоль реки Волга. Использоваися метод полного обследования пробных площацей, мия которых проводился поиск всех гнездовых участков.

Обследования территорий проводились с марта по ноябрь. В марте, апреле, октябре и ноябре осушествлялся поиск гнёзА в лесных массивах. С мая по сентябрь выявлялись гнездовые участки по жилым и пустуюшим гнёздам, встречам слётков, опекаемых родителями (Аостоверное гнездование) и встречам взрослых птиц
Eagle in the region was estimated at 21-23 breeding pairs (Bakka et al., 2010b). However, most pairs stopped breeding soon due to prolonged depression of the main prey species. Moreover, the catastrophic forest fires of 2010 affected almost all breeding territories of Golden Eagles inhabited Kamsko-Bakaldinskie bogs, which make more than $80 \%$ of the total population of the Nizhny Novgorod region. Over the past five years, only seven breeding territories have been preserved (fig.1). The current number of the species in the region is $7-16$ pairs.

\section{Imperial Eagle (Aquila heliaca)}

The only breeding territory of the Imperial Eagle known in the region is located in the Ichalkovsky pine forest. Successful breeding of the pair has not been registered since 1995 (Bakka et al., 2010a). This fact makes us think that the species has disappeared on nesting grounds. Over the past five years only two observations of Imperial Eagles have been recorded in the Nizhny Novgorod region, both practically on the border with the Republic of Mordovia (fig. 2), where the species is still nesting.

\section{Greater Spotted Eagle (Aquila clanga)}

Before 2014, the number of the Greater Spotted Eagle in the Nizhny Novgorod region was estimated at 25-30 pairs (Bakka, Kiseleva, 2008; Red Data Book, 2014). Between 2014 and 2018, 29 new territories of this species were discovered, and 3 previously known ones have been confirmed (Shukov, 2017) (fig. 3). Nests were found in 9 territories, all of them were located in flooded alder groves. The current estimate of the species population in the region is 90-100 pairs. 
в гнездовой период в гнездовых стациях (вероятное гнездование).

Аия оценки численностей видов в регионе производился ГИС-анаииз и пересчёт плошацей занятых гнездовых участков на обследованных территориях на плошали таких же местообитаний в Нижегородской области.

Всего был выявлен 151 гнездовой участок крупных хишных птиц. Обший объём полученного материала характеризует таблица 1.

\section{Беркут (Aquila chrysaetos)}

Вил занесён в Красную книгу Российской Федерации, Приложение II СИТЕС и Красную книгу Нижегородской области (2014). Статус в регионаиьной Красной книге - категория A, виА, находяшийся под угрозой исчезновения.

Беркут в Нижегородской области был обычен $\Delta$ о 1950-х гг., но уже в 1970-е гг. стаи крайне редок. К концу 1900-х гг. численность вида не превышаяа 3 гнездяшихся пар. В 2007 г. численность беркута в регионе оцениваяась уже в 21-23 гнездяшиеся пары, распределённые в трёх гнездовых группировках (камско-бакамдинская, пижемская и унженская). Этот показатель стац максимацьным итогом программы по привлечению беркута на гнездовые платформы, проводившейся в 1998-2010 гг. (Бакка и мр., 2010b). ОАнако, уже начиная с 2008 г., был отмечен процесс опустения гнездовых участков наиболее значимой, камско-бакамдинской группировки в связи с Аепрессией основных видов Аобычи (заяц-беляк и тетеревиные). Кроме того, именно эта территория катастросическим образом пострахала от лесных пожаров в аномамьно жаркое лето 2010 г. Практически все места гнездования беркутов были затронуты огнём - многие гнёзаа сгорели, а в сохранившихся не были выявлены следы размножения в последуюшие годы.

За последние пять лет на территории Нижегородской области была подтвержлена сохранность только семи гнездовых участков беркута

Птенец беркута (Aquila chrysaetos) в гнезде. Фото П. Шукова. A nestling of the Golden Eagle (Aquila chrysaetos) in the nest. Photo by P. Shukov.
Lesser Spotted Eagle (Aquila pomarina)

Before 2016, the only one observation of the Lesser Spotted Eagle in the Nizhny Novgorod region was known (Bakka, Kiseleva, 2017). In 2016 and 2017, adult individuals were observed in three areas (fig. 4), which confirms the species range expansion to the east (Melnikov, Chudnenko, 2017; Romanov et al., 2017). The facts of nesting of the Lesser Spotted Eagle in the region are to be confirmed in the future.

\section{Booted Eagle (Hieraaetus pennatus)}

In 2002-2008, the density of the Booted Eagle in the suitable nesting biotopes of the Nizhny Novgorod region was 12.6 pairs $/ 100 \mathrm{~km}^{2}$ and the population of the species was estimated at 104-111 pairs (2014). Over the past 5 years Booted Eagles have been observed on 25 territories (fig.5). Thus, we may talk about the continued species range expansion to the north and estimate the current number of the Booted Eagle in the region at 120130 pairs.

\section{White-Tailed Eagle (Haliaeetus albicilla)}

Before 2014, the population of the White-Tailed Eagle in the Nizhny Novgorod region was estimated at 40-60 pairs. Between 2014 and 2018, we found 24 new breeding territories of the species in the region, and 8 previously known territories were confirmed (fig.6). Nine newly found territories located near large ponds and peat quarries, which makes it possible to assume that the density of the WhiteTailed Eagle along the rivers of Oka and Volga has reached its maximum. The current estimate of the species population in the region is $70-80$ pairs.

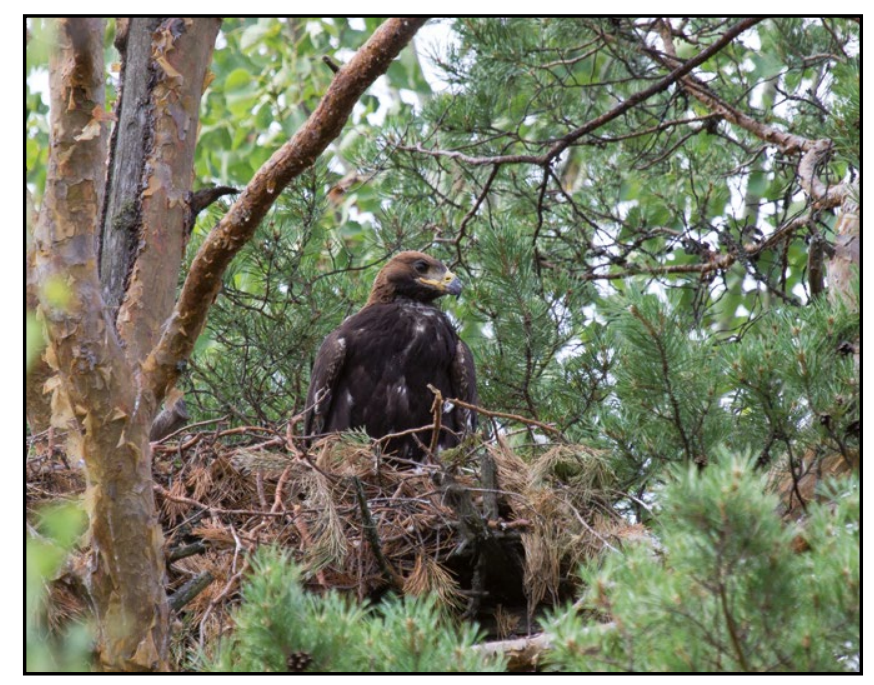




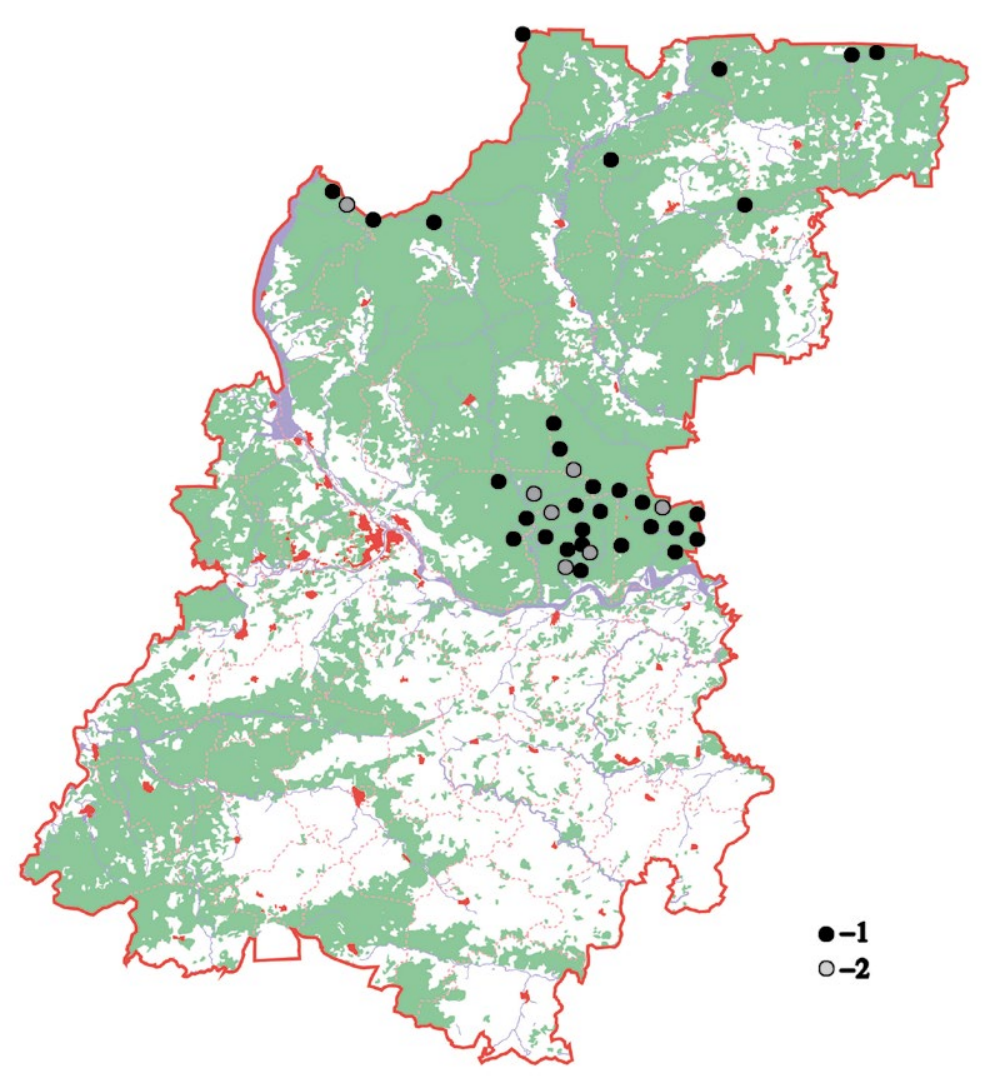

(рис. 1). На шести территориях камскобакамдинской группировки наблюдамись взрослые птицы в периол размножения и отмечены факты посешения присац, также подтвержАён факт гнездования на одном участке унженской группировки. Современная численность вида в регионе, на основании проведённого анамиза, нами оценивается в 7-16 гнездяшихся пар. Аля более точного установления численности беркута необходим специальный проект, вкАючаюший, помимо прочего, и новый план по установке гнездовых платсрорм.

\section{Орёл-могимьник (Aquila heliaca)}

Виц занесён в Красную книгу Российской Федерации, Красную книгу МСОП, Приложение I СИТЕС и Красную книгу Нижегородской области (2014). Статус в региональной Красной книге - категория А, вид, находяшийся под угрозой исчезновения.

На единственном известном в регионе гнездовом участке могильника в Ичалковском бору успешное размножение пары не регистрировалось с 1995 г. (Бакка и $\Delta$, 2010а). Этот факт позволяет считать виА исчезнувшим на гнездовании в регионе. Основная причина - деграхация кормовой базы вследствие упахка пастбишного скотоводства. В начаме 2000-х гг. метуюшие особи несколько раз отмечались в
Рис. 1. Гнездовые участки беркута (Aquila chrysaetos) в Нижегородской области: 1 - известные до 2014 г., 2 - подтвержАённые в 2014-2018 гг.

Fig. 1. Breeding territories of the Golden Eagle (Aquila chrysaetos) in the Nizhny Novgorod region: 1 - known until 2014, 2 - confirmed in 2014-2018.

\section{Short-Toed Eagle (Circaetus gallicus)}

The estimation of the Short-Toed Eagle population in the Nizhny Novgorod region before 2014 is 15-20 pairs (Bakka, Kiseleva, 2009b; Red Data Book, 2014). Over the past 5 years, 35 new territories of the species have been found in the region and 4 previously known ones have been confirmed (fig. 7). We revealed that burnt areas left after the extensive fires of 2010 became the basis for many breeding territories of the Short-toed Eagle in the region. The current estimate of the species population in the region is $80-90$ pairs.

\section{Osprey (Pandion haliaetus)}

After 2000, the population of the Osprey in the Nizhny Novgorod region increased and by 2014 reached $45-50$ pairs (Red Data Book, 2014). For the period 2014-2018, 11 new Osprey breeding territories were discovered in the region and 8 previously known were confirmed (fig. 8), which allows us to assume that the growing trend of the species population is continue. The current estimate of the species population in the region is $50-60$ pairs.

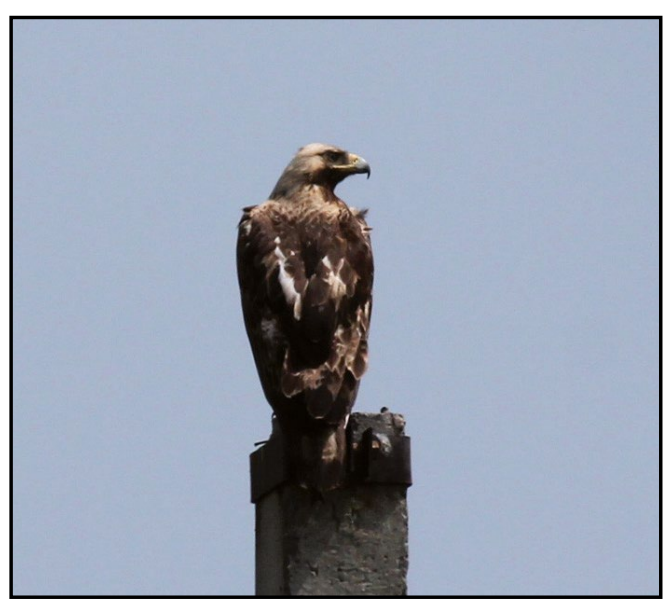

Орёл-могильник (Aquila heliaca), снятый юго-восточнее Нижегородской области в 2011 г. Фото А. Аевашкина.

The Imperial Eagle (Aquila heliaca) photographed in the southeast from the south border of the Nizhny Novgorod region in 2011. Photo by A. Levashkin. 


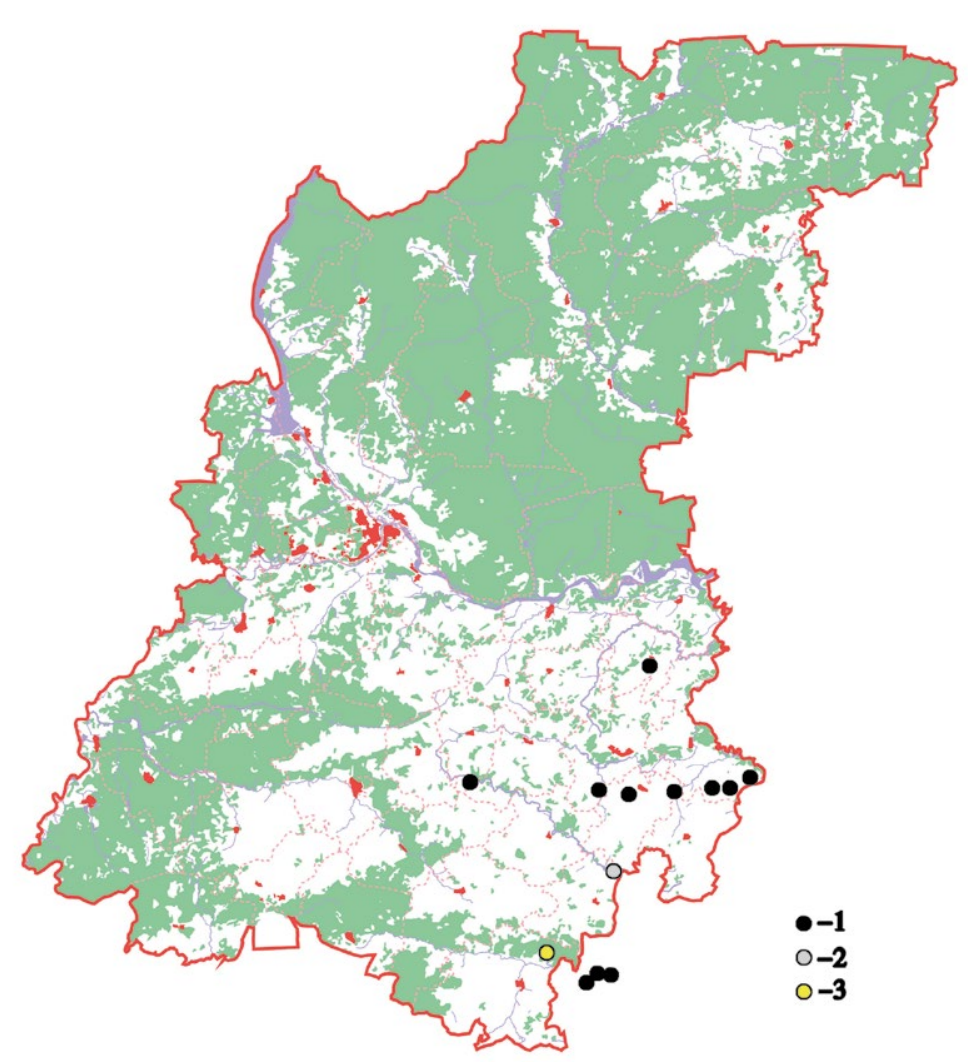

юго-восточных районах области (Красная книга, 2014).

За последние пять лет в Нижегородской области было отмечено только Аве встречи могильника, обе практически на границе с Республикой Мордовия (рис. 2). В 2016 г. взрослая птица наблюдалась в БольшеболАинском районе, а в 2017 г. - молодая в Починковском. Столь редкие фракты наблюдений птиц и отсутствие не только находок гнёзА, но и встреч взрослых особей с гнезАовым поведением, подтвержАают тезис об отсутствии гнезАо-

Рис. 3. Гнездовые участки большого подорлика (Aquila clanga) в Нижегородской области: 1 - известные до 2014 г., 2 - подтвержиённые в 2014-2018 гг., 3 - найденные в 2014-2018 гг.

Fig. 3. Breeding territories of the Greater Spotted Eagle (Aquila clanga) in the Nizhny Novgorod region: 1 - known until 2014, 2 - confirmed in 2014-2018, 3 - found in 2014-2018.
Рис. 2. Гнездовые участки орла-могимьника (Aquila heliaca) в Нижегородской области: 1 - известные $\Delta о$ 2014 г., 2 - поАтвержАённые в 2014-2018 гг., 3 - найденные в 2014-2018 гг.

Fig. 2. Breeding territories of the Imperial Eagle (Aquila heliaca) in the Nizhny Novgorod region: 1 - known until 2014, 2 - confirmed in 2014-2018, 3 - found in 2014-2018.

вых участков вила в регионе. Несмотря на наличие гнездяшихся пар орла-могильника в долинах р. Алатырь и р. Сура в Респубмике МорАовия, УАьяновской области и Республике Чувашия, не стоит ожидать изменения ситуации в Нижегородской области без возрождения пастбишного скотово Аства.

\section{Большой подорлик (Aquila clanga)}

Вид занесён в Красную книгу Российской Фелерации, Красную книгу МСОП, Приложение II СИТЕС и Красную книгу Нижегородской области (2014). Статус в регионаяьной Красной книге - категория А, вид, находяшийся под угрозой исчезновения.

Большой подорлик считался обычным видом региона в начале и середине $X X$ века, однако уже к 1970-м гг. становится малочисленным. За период 1986-2013 гг. в Нижегородской области и в непо-

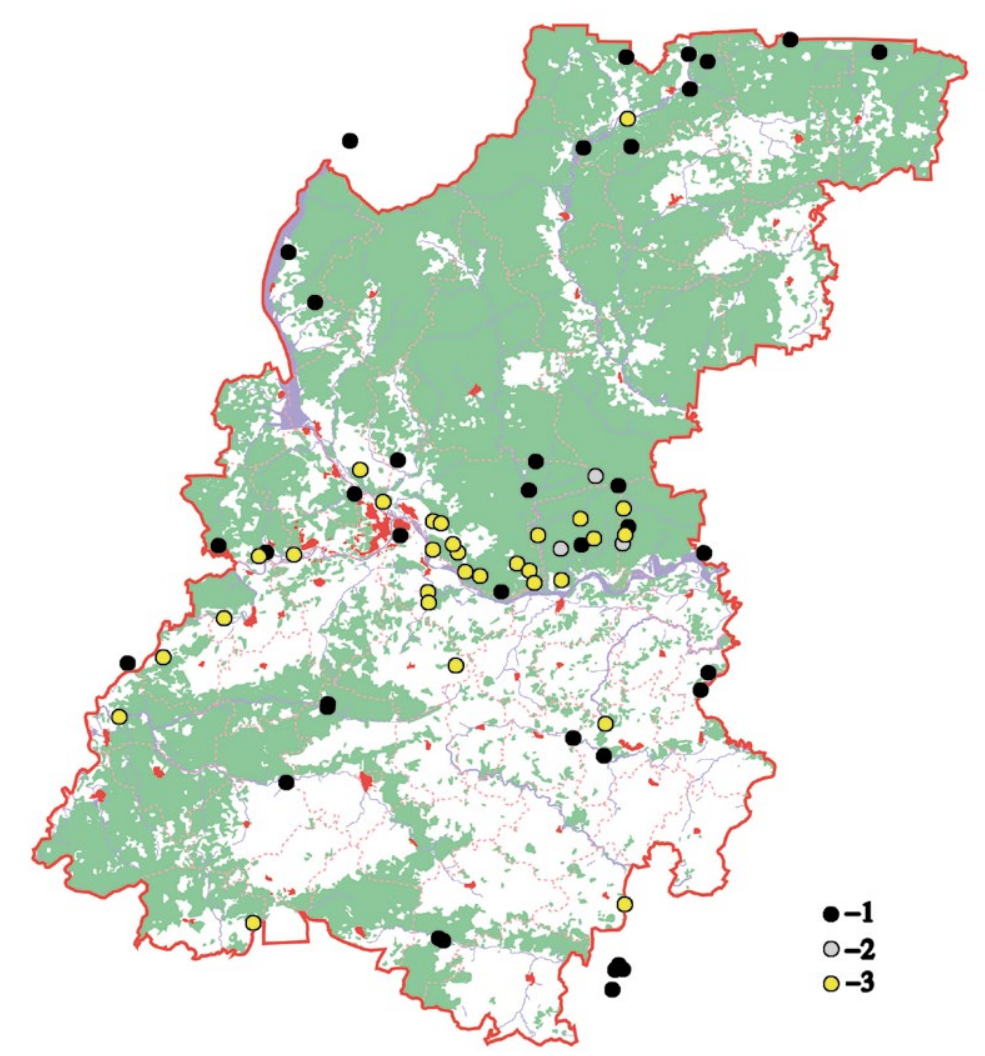




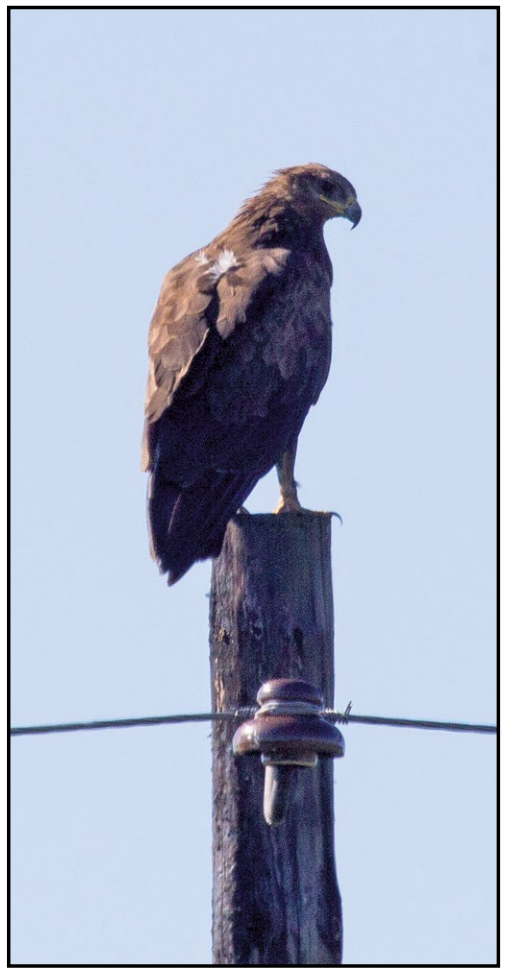

средственной близости от её границ было найдено 19 гнездовых участков большого подорлика (Бакка, Киселева, 2008). Численность вила в регионе оценивалась в 25-30 пар (Красная книга, 2014).

В течение 2014-2018 гг. автором было найдено 29 новых участков и подтверждено 3 ранее известных (рис. 3). Наибольшее количество находок гнёзд и встреч птиц (21) было выявлено в ходе обследования пойм р. Волга и её притоков в Борском, Городецком, Аысковском и Воротынском районах области, что позволяет говорить о присутствии зАесь крупной керженско-нюжменской гнезАовой группировки большого подорлика (Шуков, 2017). Четыре территории

Большой подорлик (Aquila clanga). Фото П. Шукова.

Greater Spotted Eagle (Aquila clanga). Photo by P. Shukov. было выявлено в пойменных лесах р. Ока, ешё по одной на реках Ветлуга, Тёша, Озёрка, Кудьма, Урга, Мокша, Саяя. Во всех случаях охотничьи участки вида вкиючали в себя открытые болота, пойменные луга или зарастаюшие поля и пастбиша. На 9 территориях были найдены гнёзда, все они располагамись в затопленных ольшаниках.

Плотность распоможения гнездовых участков и характер занимаемых птицами биотопов позволяет слелать предположение о присутствии большого подорлика и на некоторых $ы р у-$ гих территориях области, которые ешё не были детаиьно обследованы.
Рис. 4. Гнездовые участки мачого подорлика (Aquila pomarina) в Нижегородской области: 1 - известные Ао 2016 г., 2 - найденные в 2016-2018 гг.

Fig. 4. Breeding territories of the Lesser Spotted Eagle (Aquila pomarina) in the Nizhny Novgorod region: 1 - known until 2016, 2 - found in 2016-2018.
Современная оценка численности вида в регионе - 90-100 пар.

\section{Малый подорлик (Aquila pomarina)}

Вих занесён в Красную книгу Российской Федерации, в Красной книге Нижегородской области (2014) содержатся свеАения о единичном залёте.

$\Delta$ о 2016 г. был известен единственный факт встречи малого подорлика в Нижегородской области - одна молодая птица была Аобыта охотником в Выксунском районе в 1995 г. (Бакка, Киселева, 2017). В 2016 и 2017 гг. взрослые особи наблюАаиись на трёх участках в Борском, Кстовском и Ааиьнеконстантиновском районах (рис. 4). Таким образом, процесс расширения ареала вила на восток, отмеченный в регионах, расположенных к запалу от Нижегородской области (Мельников, Чудненко, 2017; Романов и Ар, 2017), проАолжается.

В Авух случаях выявленные участки малых подорликов соседствуют с территориями, на которых наблюдаиись большие подорлики в гнездовой период. Так как дяя этих Авух виАов установлены факты гибриАизации (Аомбровский, 2009), то весьма вероятно, что Аанный процесс характерен и мля Нижегородской области. ОАнако факты, подтвержАаюшие это, предстоит установить в будушем.

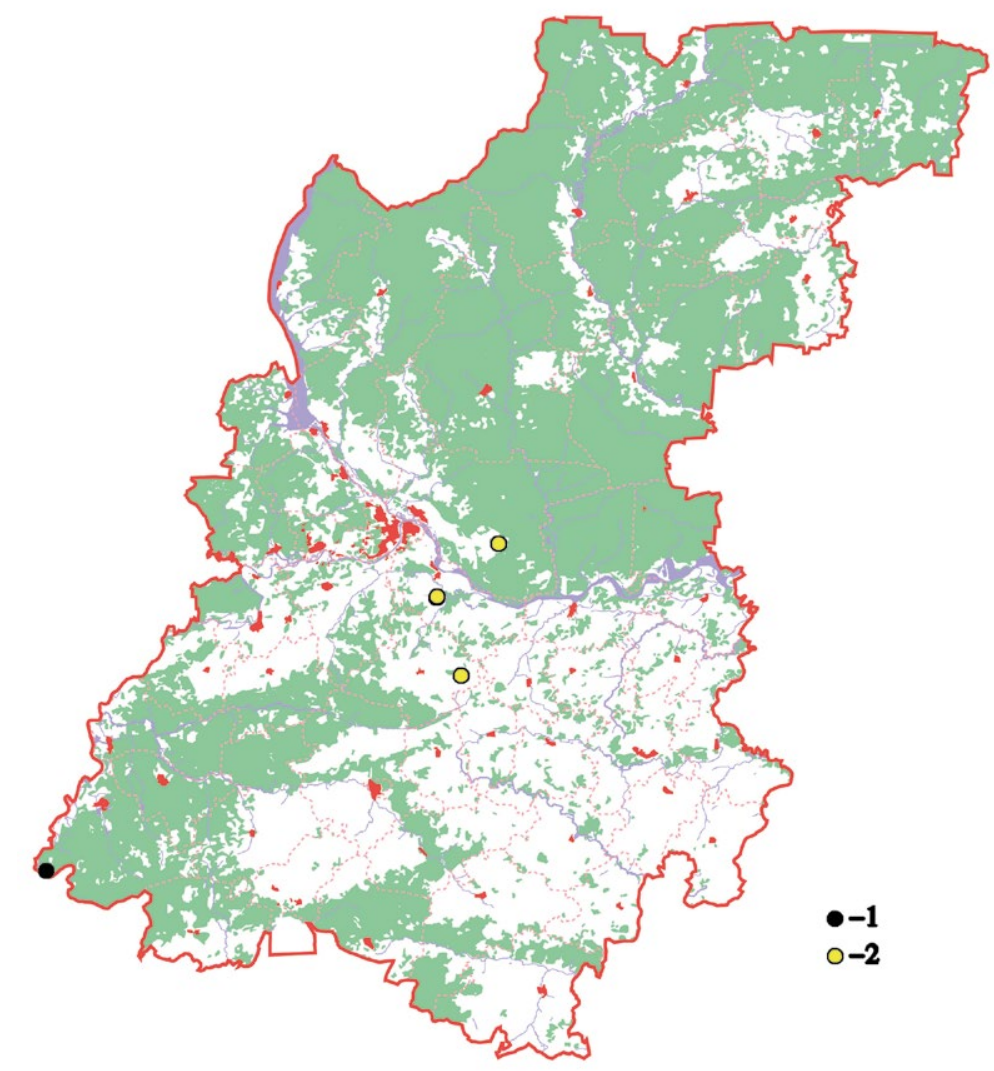




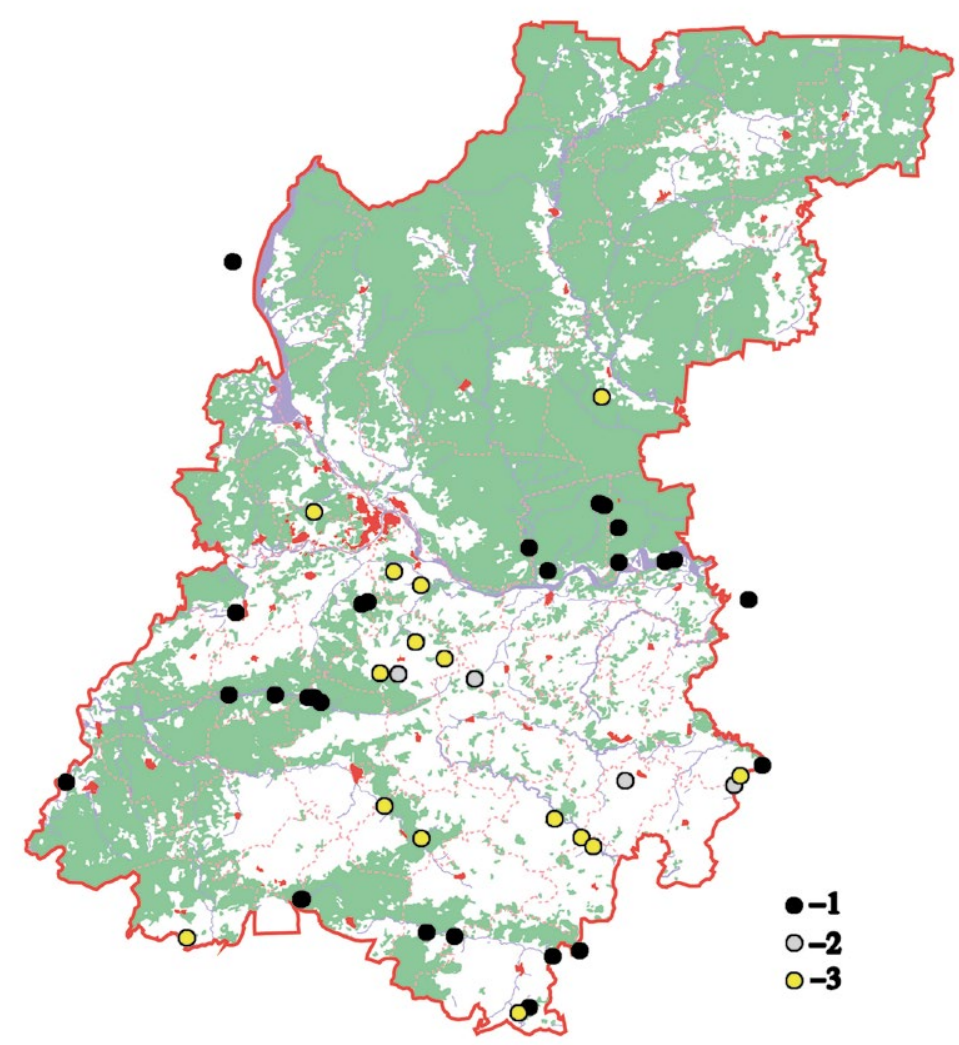

Рис. 5. Гнездовые участки орла-карлика (Hieraaetus pennatus) в Нижегородской области: 1 - известные до 2014 г., 2 - подтвержАённые в 2014-2018 гг., 3 - найАенные в 2014-2018 гг.

Fig. 5. Breeding territories of the Booted Eagle (Hieraaetus pennatus) in the Nizhny Novgorod region: 1 - known until 2014, 2 - confirmed in 2014-2018, 3 - found in 2014-2018.

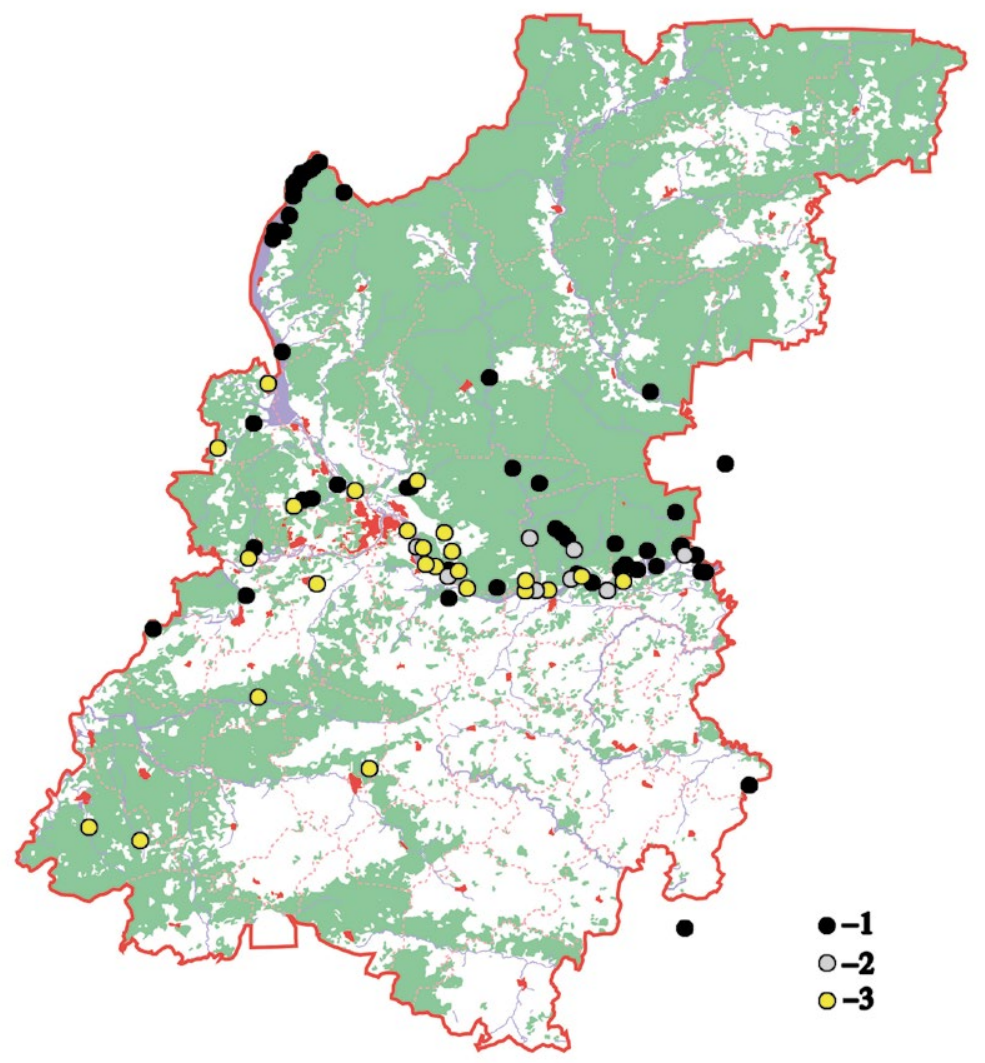

\section{Oрёл-карлик (Hieraaetus pennatus)}

Вид занесён в Приложение к Красной книге Российской Федерации, Приложение II СИТЕС и Красную книгу Нижегородской области (2014). Статус в регионамьной Красной книге - категория В2, редкий виА, находяшийся на границе ареала.

В конце 1990-х гг. численность орлакарлика в регионе оценивалась в 10-15 гнездяшихся пар, в последствии шло активное расширение ареала вида в бассейне Волги и к 2002-2008 гг. плотность орла-карлика в гнездопригодных биотопах Нижегородской области составила 12,6 пар/100 км², а численность вила была оценена в 104-111 пар (Красная книга, 2014).

За последние 5 лет птицы наблюдались на 19 участках (15 новых и 4 подтверж-

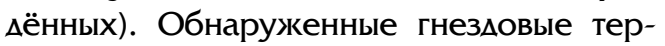
ритории располагались в смешанных и лиственных лесах по Аолинам рек Предволжья (рис. 5). Только в одном случае взрослая особь в период размножения наблюдалась в Заволжье - в Воскресенском районе к востоку от р. Ветлуга. Эта точка пока является самой северной мля орлакарлика в Нижегородской области. Таким образом, можно говорить о продолжаюшемся расширении ареала вида на север и оценить современную численность орлакарлика в регионе в 120-130 пар.

\section{Орлан-белохвост (Haliaeetus albicilla)}

Вид занесён в Красную книгу Российской Федерации, Приложение I СИТЕС и Красную книгу Нижегородской области (2014). Статус в регионамьной Красной книге - категория А, вид, находяшийся под угрозой исчезновения.

Ретроспективный анализ численности орлана-белохвоста в регионе позволяет предполагать гнездование в начале $X X$ века 80-100 пар птиц. ОАнако последуюшее пахение численности привело к тому, что в первой половине 1980-х гг. на территории Нижегородской области гнездилось всего 4-7 пар этого вила (Красная Книга, 2014). Ситуация улучшалась в течение 1990-х и 2000-х гг. и по последней оцен-

Pис. 6. Гнездовые участки орлана-белохвоста (Haliaeetus albicilla) в Нижегородской области: 1 - известные $о$ о 2014 г., 2 - подтверждённые в 2014-2018 гг., 3 - найденные в 2014-2018 гг.

Fig. 6. Breeding territories of the White-Tailed Eagle (Haliaeetus albicilla) in the Nizhny Novgorod region: 1 - known until 2014, 2 - confirmed in 2014-2018, 3 - found in 2014-2018. 
Орлан-белохвост (Haliaeetus albicilla). Фото П. Шукова.

White-Tailed Eagle (Haliaeetus albicilla). Photo by P. Shukov.

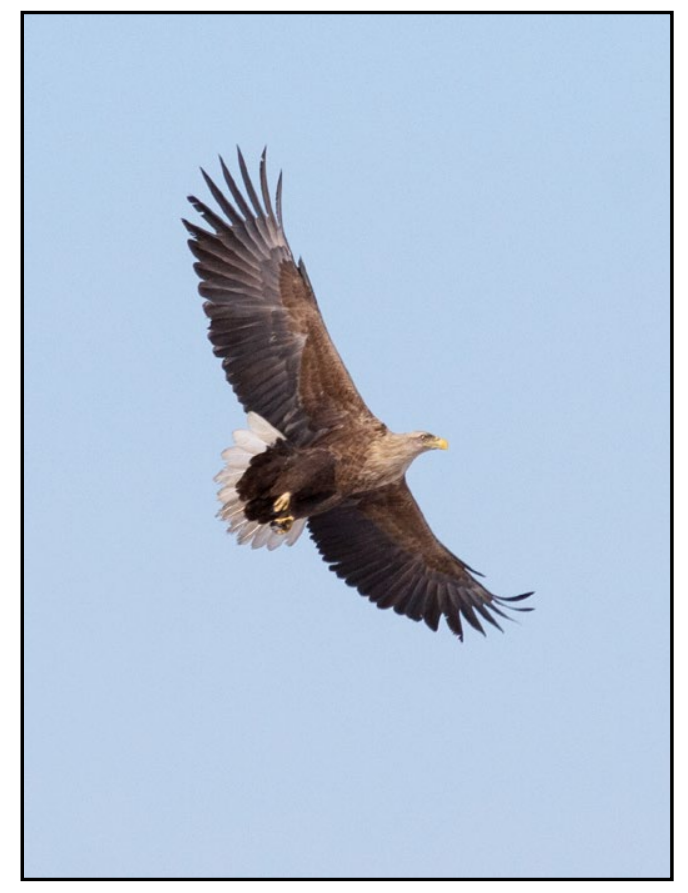

ке, которая была произведена в 2008 г., численность орлана-белохвоста в Нижегородской области составила 40-60 пар. Абсолютное большинство обнаруженных на тот момент гнездовых территорий располагалось по Аолинам крупных рек, а максимаиьная плотность наблюдалась по берегам Горьковского и Чебоксарского водохранилиш. Было слелано предположение, что вих заселил большинство пригодных местообитаний в этих районах (Бакка, Киселева, 2009a).

В период 20142018 гг. было поАтвержиено 8 участков орланов и обнаружено 24 новых гнездовых территории (рис. 6). При этом, 9 новых участков оказаиись расположены у крупных прудов и систем водоёмов выработанных торсяяных
Pис. 7. Гнездовые участки змееяла (Circaetus gallicus) в Нижегородской области: 1 - известные Ао 2014 г., 2 - подтвержАённые в 2014-2018 гг., 3 - найденные в 2014-2018 гг.

Fig. 7. Breeding territories of the Short-toed Eagle (Circaetus gallicus) in the Nizhny Novgorod region: 1 - known until 2014, 2 - confirmed in 2014-2018, 3 - found in 2014-2018. месторождений. Отмеченная тенденция позволяет слелать предположение о том, что плотность орлана-белохвоста сейчас Аостигла своего максимума не только по берегам водохранилиш, но и вдоль рек Волга и Ока в целом, и вил сейчас занимает новые мия себя территории, часто удалённые от речных цолин. Современная оценка численности вида в регионе - 70-80 пар, но мия получения более точных Аанных необходимо специаиьное обследование прибрежных лесов вАоль крупных рек региона.

Также нужно отметить, что вид меняет свой статус с гнездяшегося перелётного на осёдмый. Первые факты зимовки орланов в регионе были отмечены в начале 2000-х гг. (Бакка, Киселева, 2017), а за последние пять лет пары орланов все чаше наблюдаются зимой на своих гнездовых участках. Также отмечаются встречи в зимний периоА скоплений молодых птиц у крупных c/x комплексов и свалок. Всего было обнаружено 10 новых территорий, на которых орланы зимуют в Нижегородской области.

\section{Змееям (Circaetus gallicus)}

Вид занесён в Красную книгу Российской Федерации, Приложение II СИТЕС и Красную книгу Нижегородской области. Статус в регионаиьной Красной книге - категория А, виА, находяшийся под угрозой исчезновения.

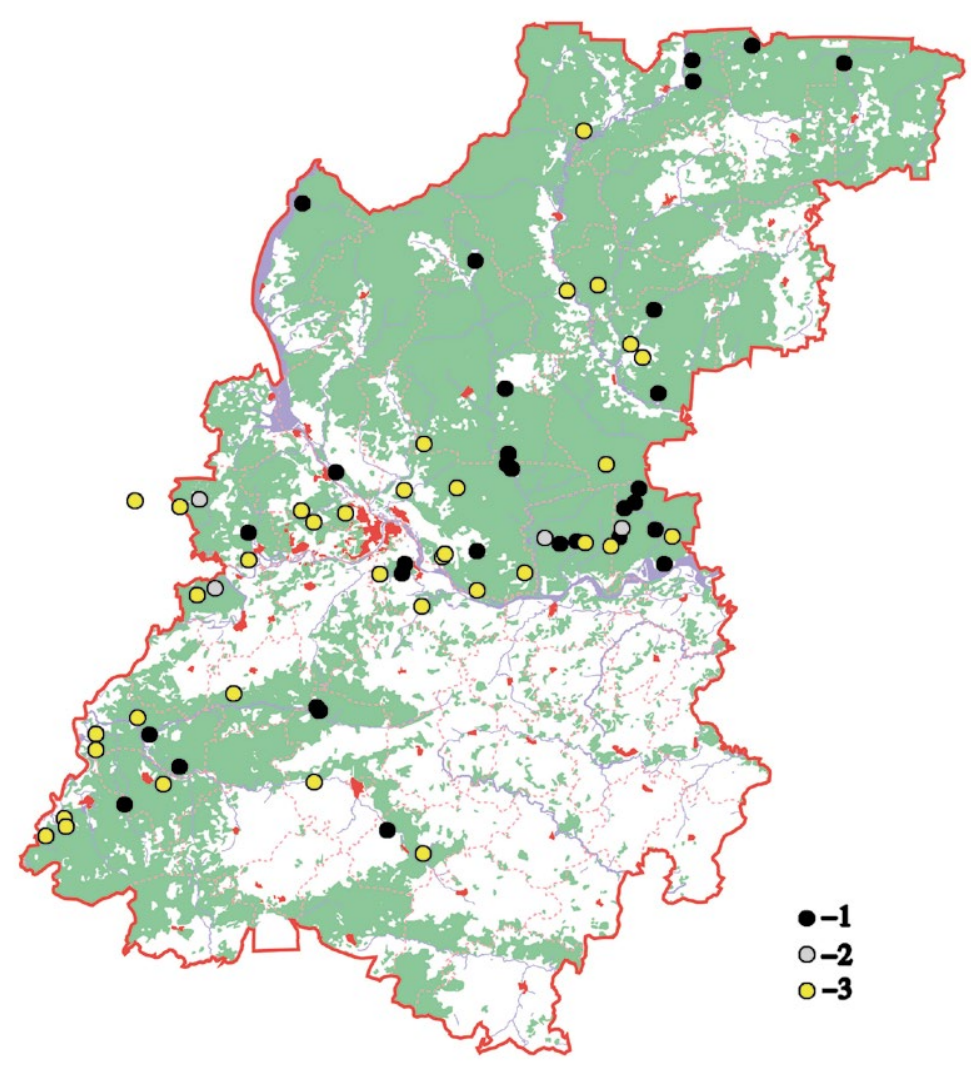


Змееян

(Circaetus gallicus). Фото П. Шукова.

Short-Toed Eagle (Circaetus gallicus). Photo by P. Shukov.

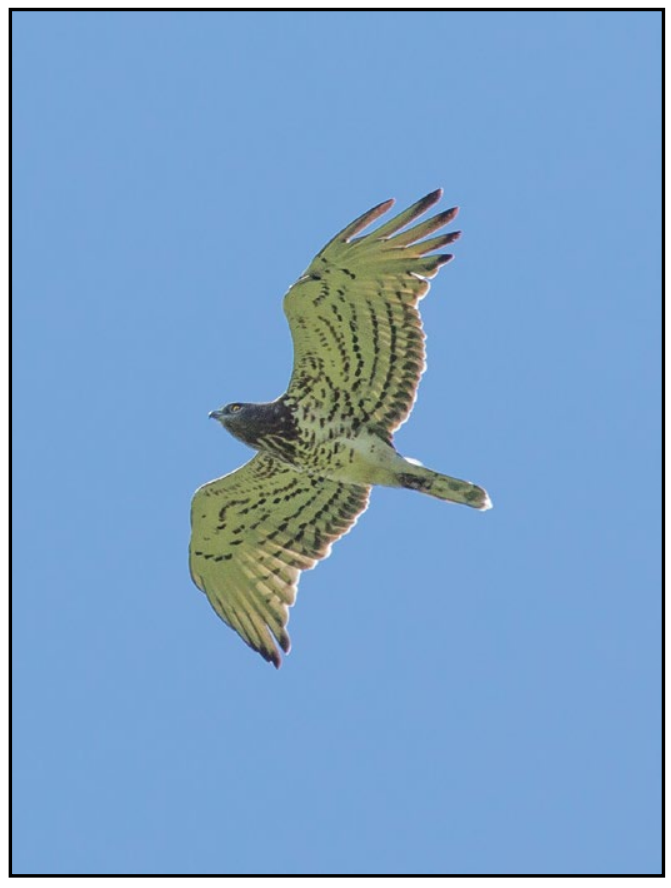

В 1990-х гг. численность змееяла в Нижегородской области оценивалась в 5-9 гнездяшихся пар, в последствии этот показатель был уточнён при помоши ГИСанализа и вплоть $А$ 2014 г. составлял 1520 пар (Бакка, Киселёва, 2009b; Красная книга, 2014).

За последние 5 лет было найдено 35 новых участков вида в регионе и подтверждено 4 ранее известных (рис. 7). Новые

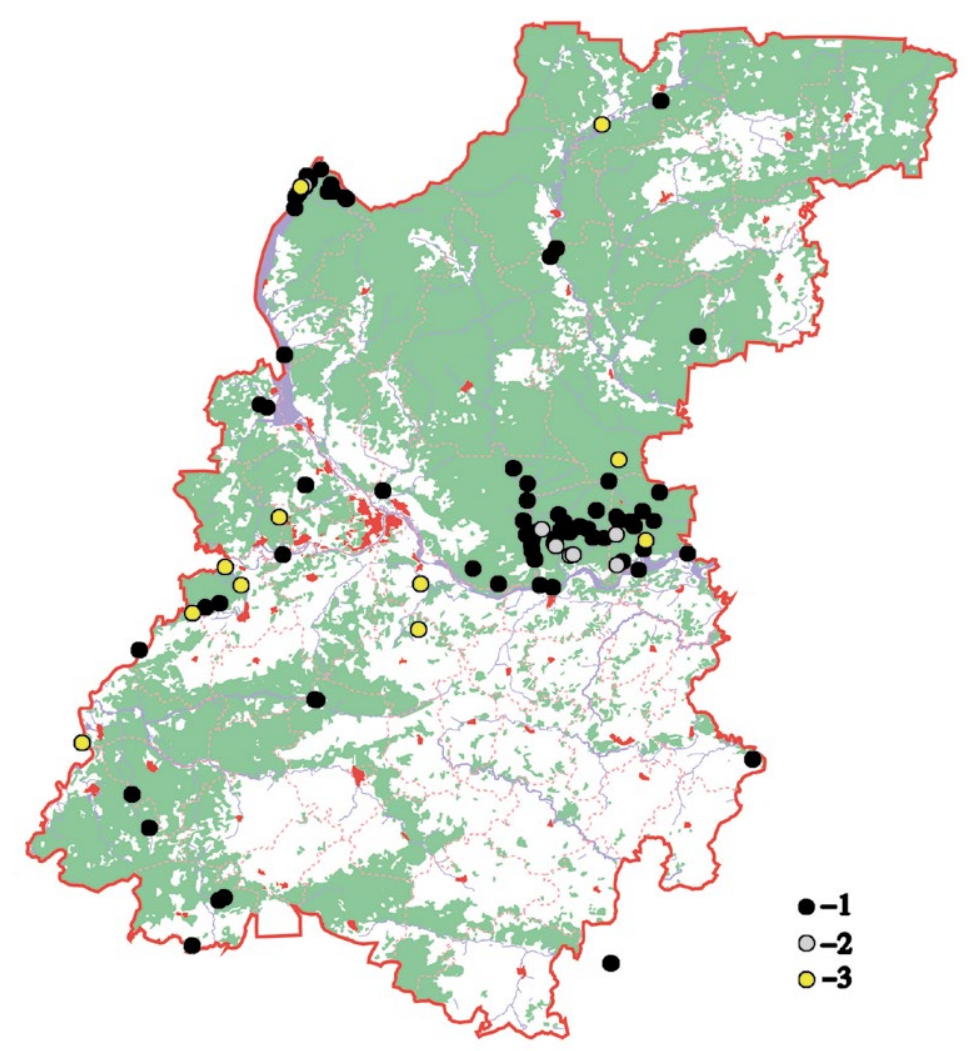

территории располаганись на гарях, верховых болотах, пойменных кугах и зарастаюших полях. В том числе, в 2016 г. были получены первые факты доказанного размножения вида - обнаружено жилое гнезАО в Володарском районе (А.П. Аевашкин, мичное сообшение) и наблюдалась пара со слётком в Воскресенском районе. Можно утвержлать, что обширные гари, образовавшиеся после пожаров 2010 г., стаии основой мия многих гнездовых территорий змееяла в Нижегородской области. Современная оценка численности вила в регионе - 80-90 пар.

\section{Cкопа (Pandion haliaetus)}

Вих занесён в Красную книгу Российской ФеАерации, Приложение II СИТЕС и Красную книгу Нижегородской области. Статус в регионамьной Красной книге - категория А, виА, находяшийся под угрозой исчезновения.

Скопа, считавшаяся в регионе в 1950-60 гг. обычным видом, в начале 1970-х гг. стала редкой, а к концу 1990-х гг. её численность оценивалась в 10-15 гнездяшихся пар. После 2000 г. численность скопы в Нижегородской области возрастала, чему в значительной степени способствовала программа по установке гнездовых платформ, и к 2014 г. оценивалась в 45-50 пар (Красная Книга, 2014).

За период 2014-2018 гг. было обнаружено 11 новых участков скопы в регионе и подтверждено 8 ранее известных (рис. 8). Все подтвержлённые местообитания находились в пределах двух основных группировок скопы в регионе - на Камско-Бакаминских болотах и у побережья Горьковского водохранилиша в Сокольском районе области. На этих территориях было найдено по одному новому гнездовому участку скопы, а также новые участки были обнаружены на реках Волга, Ока, Ветлуга, Стройка и Кудьма. Полученные данные позволяют предполагать сохранение тенденции роста численности вида на территории Нижегородской области и оценить численность в 50-60 гнезАяшихся пар.

Рис. 8. Гнездовые участки скопы (Pandion haliaetus) в Нижегородской области: 1 - известные Ао 2014 г., 2 - подтверждённые в 2014-2018 гг., 3 - найденные в 2014-2018 гг.

Fig. 8. Breeding territories of the Osprey (Pandion haliaetus) in the Nizhny Novgorod Region: 1 - known until 2014, 2 - confirmed in 2014-2018, 3 - found in 2014-2018. 


\section{Митература:}

Бакка С.В., Киселёва Н.Ю. Большой подормик в Нижегородской области. - Пернатые хишники и их охрана. 2008. № 11. С. 70-72. [Bakka S.V., Kiseleva N.Yu. The Greater Spotted Eagle in the N.Novgorod District. - Raptors Conservation. 2008. 11: 70-72.] URL: http:// rrrcn.ru/ru/archives/25026 Аата обрашения: 20.11.2018.

Бакка С.В., Киселёва Н.Ю. Орлан-белохвост в Нижегородской области, Россия. - Пернатые хищники и их охрана. 2009 а. № 13 С. 21-27. [Bakka S.V., Kiseleva N.Yu. The WhiteTailed Eagle in the N.Novgorod District, Russia. Raptors Conservation. 2009 a. 13: 21-27.] URL: http://rrrcn.ru/ru/archives/24900 Аата обрашения: 20.11.2018.

Бакка С.В., Киселёва Н.Ю. Распространение и численность змееяла в Нижегородской области, Россия. - Пернатые хишники и их охрана. 2009 b. № 17. C. 121-124. [Bakka S.V., Kiseleva N.Yu. Distribution and Number of the ShortToed Eagle in the N. Novgorod District, Russia. - Raptors Conservation. 2009 b. 17: 121-124.] URL: http://rrrcn.ru/ru/archives/19453 Аата обрашения: 20.11.2018.

Бакка С.В., Киселёва Н.Ю. Орнитофауна центра Европейской России: динамика, антропогенная трансформация, пути сохранения: монограсия. М.: ФЛИНТА; Нижний Новгород: Мининский университет, 2017. 260 c. [Bakka S.V., Kiseleva N.Yu.The avifauna of the center of European Russia: dynamics, anthropogenic transformation, ways of preservation: a monograph. Moscow; Nizhny Novgorod, 2017: 1-260. (in Russian).] URL: http://book.mininuniver.ru/ books/Bakka_Ornitofauna_centra_Evropeiskoi_ Rossii Аата обрашения: 20.11.2018.

Бакка С.В., Киселёва Н.Ю., Карякин И.В. Могильник в Нижегородской области, Россия. - Пернатые хишники и их охрана. 2010а. № 20. C. 84-88. [Bakka S.V., Kiseleva N.Yu. The Imperial Eagle in the Nizhniy Novgorod District, Russia. - Raptors Conservation. 2010 a. 20: 8488.] URL: http://rrrcn.ru/ru/archives/19243 $\triangle$ ата обрашения: 20.11.2018.

Бакка С.В., Карякин И.В., Киселёва Н.Ю., $\triangle$ енисов А.А., Карпеев В.Е., Левашкин А.П., Некрасов М.С. Итоги мониторинга состояния и охраны гнездовых группировок редких виАОв Аневных хишных птиц в Нижегородской области в 1988-2009 годах, Россия. - Пернатые хишники и их охрана. 2010 ь. № 18. С. 46-67. [Bakka S.V., Karyakin I.V, Kiseleva N.Yu., Denisov D.A., Karpeev V.E., Levashkin A.P., Nekrasov M.S. Results of the Monitoring on Status of Breeding Groups of Rare Raptor Species and their Conservation in the N. Novgorod District in 1988-2009, Russia. - Raptors
Conservation. 2010b. 18: 46-67.] URL: http:// rrrcn.ru/ru/archives/19378 Аата обрашения: 20.11.2018.

Аомбровский В.Ч. О виАОвой идентисрикации малого, большого подорликов и их гибридов в полевых условиях. - Пернатые хищники и их охрана. 2009. № 15. С. 97-110. [Dombrovski V.C. About Species Identification of Lesser and Greater Spotted Eagles and their Hybrids in the Field Conditions. - Raptors Conservation. 2009. 15: 97-110.] URL: http:// rrrcn.ru/ru/archives/21073 Аата обрашения: 20.11.2018.

Красная книга Нижегородской области. Том 1. Животные. 2-е изА., перераб. и $ы$ пп. 2014. 448 c. [The Red Data Book of the Nizhny Novgorod region. Volume 1. Animals. 2nd ed. 2014: 1-448. (in Russian).] URL: http://mineconn.ru/File/red_book.rar $\Delta$ aта обрашения: 20.11.2018.

Мельников В.Н., Чудненко А.Е. Обзор Аневных хишных птиц Ивановской области. - Вестник Ивановского государственного университета. Серия: Естественные, обшественные науки. 2017. № 2. С. 32-44. [Melnikov V.N., Chudnenko D.E. A review of Ivanovo region raptors. - Ivanovo State University Bulletin. Series "Natural, Social Sciences». 2017. 2: 32-44. (in Russian).] URL: http://ivanovo.ac.ru/upload/ medialibrary/68b/Vestnik_IvSU_EstNauki_2-2017. PDF Аата обрашения: 20.11.2018.

Романов В.В., Быков Ю.А., Сергеев М.А. Новые сведения о соколообразных птицах Влацимирской области. - Русский орнитологический журнал. 2017. Т. 26. № 1494. С. 3692-3696. [Romanov V.V., Bykov. Yu.A., Sergeev M.A. New information about birds of prey in the Vladimir Oblast. - The Russian Journal of Ornithology. 2017. 26(1494). 3692-3696. (in Russian).] URL: https://ornis.su/downloads/category/-25-2017. h t m l ? d ow n lo ad = $1499 \% 3$ A 2017 1494\&start=100 Аата обрашения: 20.11.2018.

Шуков П.М. Большой подорлик как индикатор ценных природных территорий. Проблемы природопользования и экологическая ситуация в Европейской России и на сопредельных территориях. Материалы VII Международной научной консеренции (памяти проф. Петина А.Н.). Белгород, 2017. C. 493-495. [Shukov P.M. Greater Spotted Eagle as an indicator of valuable natural areas. - Problems of nature management and the environmental situation in European Russia and in adjacent territories. Materials of the VII International Scientific Conference (in memory of prof. A. Petin). Belgorod, 2017: 493-495. (in Russian).] URL: http://elib.bsu. by/bitstream/123456789/187263/1/Kazlou_ BelGU_2017.pdf Аата обрашения: 20.11.2018. 